\title{
Antibacterial, antioxidant and tyrosinase-inhibition activities of pomegranate fruit peel methanolic extract
}

\author{
Olaniyi A Fawole ${ }^{1}$, Nokwanda P Makunga² and Umezuruike Linus Opara ${ }^{1 *}$
}

\begin{abstract}
Background: This study evaluated, using in vitro assays, the antibacterial, antioxidant, and tyrosinase-inhibition activities of methanolic extracts from peels of seven commercially grown pomegranate cultivars.

Methods: Antibacterial activity was tested on Gram-positive (Bacillus subtilis and Staphylococcus aureus) and Gram-negative bacteria (Escherichia coli and Klebsiella pneumonia) using a microdilution method. Several potential antioxidant activities, including radical-scavenging ability (RSA), ferrous ion chelating (FIC) and ferric ion reducing antioxidant power (FRAP), were evaluated. Tyrosinase enzyme inhibition was investigated against monophenolase (tyrosine) and diphenolase (DOPA), with arbutin and kojic acid as positive controls. Furthermore, phenolic contents including total flavonoid content (TFC), gallotannin content (GTC) and total anthocyanin content (TAC) were determined using colourimetric methods. HPLC-ESI/MS ${ }^{n}$ analysis of phenolic composition of methanolic extracts was also performed.
\end{abstract}

Results: Methanolic peel extracts showed strong broad-spectrum activity against Gram-positive and Gram-negative bacteria, with the minimum inhibitory concentrations (MIC) ranging from 0.2 to $0.78 \mathrm{mg} / \mathrm{ml}$. At the highest concentration tested $(1000 \mu \mathrm{g} / \mathrm{ml})$, radical scavenging activities were significantly higher in Arakta $(83.54 \%)$, Ganesh (83.56\%), and Ruby (83.34\%) cultivars $(P<0.05)$. Dose dependent FIC and FRAP activities were exhibited by all the peel extracts. All extracts also exhibited high inhibition ( $>50 \%)$ against monophenolase and diphenolase activities at the highest screening concentration. The most active peel extract was the Bhagwa cultivar against monophenolase and the Arakta cultivar against diphenolase with $I_{50}$ values of $3.66 \mu \mathrm{g} / \mathrm{ml}$ and $15.88 \mu \mathrm{g} / \mathrm{ml}$, respectively. High amounts of phenolic compounds were found in peel extracts with the highest and lowest total phenolic contents of 295.5 (Ganesh) and $179.3 \mathrm{mg} / \mathrm{g}$ dry extract (Molla de Elche), respectively. Catechin, epicatechin, ellagic acid and gallic acid were found in all cultivars, of which ellagic acid was the most abundant comprising of more than $50 \%$ of total phenolic compounds detected in each cultivar.

Conclusions: The present study showed that the tested pomegranate peels exhibited strong antibacterial, antioxidant and tyrosinase-inhibition activities. These results suggest that pomegranate fruit peel could be exploited as a potential source of natural antimicrobial and antioxidant agents as well as tyrosinase inhibitors.

Keywords: Antibacterial activity, Tyrosinase-inhibition, Phenolics, Pomegranate, South Africa

\footnotetext{
* Correspondence: opara@sun.ac.za

'Postharvest Technology Research Laboratory, South African Research Chair in Postharvest Technology, Faculty of AgriSciences, Stellenbosch University, Private Bag X1, Stellenbosch 7602, South Africa

Full list of author information is available at the end of the article
} 


\section{Background}

Numerous epidemiological studies suggest that diets rich in phytochemicals and antioxidants have protective roles in health and disease [1]. These natural antioxidants might play an important role in combating oxidative stress associated with degenerative diseases such as cancer, cardiovascular diseases, diabetes, Alzheimer's disease and aging $[2,3]$. The antioxidative phytochemicals, especially phenolic compounds, found in vegetables and fruits have received increasing attention for their potential role in the prevention of human diseases [4-8].

Pomegranate (Punica granatum L.; Punicaceae) has gained popularity in recent years due to its multifunctionality and nutritional benefit in the human diet. The fruit is rich in tannins and other biochemicals, particularly phenolics, which have been reported to reduce disease risk $[9,10]$. Pomegranate fruit peel constitutes about $50 \%$ of the total fruit weight [11], and it is often discarded as waste. However, the fruit peel contains higher amounts of polyphenol compounds than the juice, and it possesses stronger biological activities [12-14]. Studies have shown that pomegranate peel extract had markedly higher antioxidant capacity than juice extract in scavenging against superoxide anion, hydroxyl and peroxyl radicals and it inhibited $\mathrm{CuSO}_{4}$-induced $\mathrm{LDL}$ oxidation [12]. Besides high antioxidant capacity, pomegranate peel extracts have been reported to possess a wide range of biological actions including anti-cancer activity [15-17], antimicrobial activity [18,19], antidiarrheal activity [20], apoptotic and anti-genotoxic properties [21,22], anti-tyrosinase activity [23], antiinflammatory and anti-diabetic activities [24,25]. Polyphenol compounds such as ellagic tannins, flavonols, anthocyanins, catechin, procyanidins, ellagic acid and gallic acid have been implicated in various pharmacological activities in the fruit peel [24-26]. However, the levels of these compounds in the pomegranate peel may vary among pomegranate cultivars which may result in differing levels of bioactivity [27].

In South Africa, more than ten pomegranate cultivars are being commercially cultivated [28]. Till date, there is no available information on bioactivities of fruit peels of pomegranate cultivars grown under South African agroclimatic conditions. If fruit peels of pomegranate cultivars show potential to improve human health, their utilisation should be encouraged during fruit processing. In the quest to promote the development of functional foods with health-benefiting properties, we investigated the antibacterial, antioxidant, and tyrosinase-inhibition activities of extracts from peels, using in vitro assays, of seven commercially pomegranate cultivars grown in the Western Cape, South Africa. Furthermore, the total phenolic content including flavonoid, gallotannin and anthocyanin content, and individual phenolics were quantified.

\section{Methods}

Plant material

The studies were performed on peels of seven pomegranate fruit cultivars (Arakta, Bhagwa, Ganesh, Herskawitz, Molla de Elche, Ruby, and Wonderful) which are commercially grown in South Africa. Fruit were procured from a commercial pomegranate pack house in Porterville (Western Cape Province). Fruit were harvested between February and May 2010, packed in paperboard cartons and transported in air-conditioned car to the Postharvest Research Laboratory. Immediately on arrival in the laboratory, ten fruits per cultivar were washed and manually peeled. The peels were freeze-dried, ground into powder form, and stored in airtight containers at $7^{\circ} \mathrm{C}$ in the dark.

\section{Preparation of peel extract}

For each cultivar, each finely-powdered peel sample $(2 \mathrm{~g})$ was extracted separately with $10 \mathrm{ml}$ of $80 \%(\mathrm{v} / \mathrm{v})$ methanol $(\mathrm{MeOH})$ and distilled water (aqueous) by sonication for $1 \mathrm{~h} \mathrm{[29]}$. The extract was filtered under vacuum through Whatman No.1 filter paper, and the residue was reextracted further following the same procedure. Extracts were air-dried under a stream of air and first tested in the antibacterial assay to determine which extracts would be worth subjecting to further pharmacological investigations. Only the methanol extract was tested further in other assays, as it recorded highest antibacterial activity.

\section{Antibacterial property}

\section{Microdilution antibacterial assay}

The antibacterial activity of peel extract was tested using the microdilution antibacterial assay for the minimum inhibitory concentration (MIC) values [30] as detailed by Fawole et al. [31], except that in the present study the initial concentration $(50 \mathrm{mg} / \mathrm{ml})$ of the sample was prepared by dissolving dried extracts in $80 \%(\mathrm{v} / \mathrm{v})$ methanol. Two Gram-negative bacteria (Escherichia coli ATCC 11775 and Klebsiella pneumonia ATCC 13883) and two Gram-positive bacteria (Bacillus subtilis ATCC 6051 and Staphylococcus aureus ATCC 12600) were used. The extract was serially diluted two-folds with sterile distilled water in a 96-well micro-plate in triplicate for each of the four bacteria used. Streptomycin $(0.1 \mathrm{mg} / \mathrm{ml})$ was used as positive control, while water and bacteria-free broth were included as negative controls under the same conditions. Methanol (80\%) was also included to check for false antibacterial activity. The final concentration of pomegranate extract ranged from $0.097-12.5 \mathrm{mg} / \mathrm{ml}$, reducing the methanol content in the test extract to between 0.19 and $20 \%$, whereas streptomycin was between 0.78 and $100 \mu \mathrm{g} / \mathrm{ml}$. 


\section{Antioxidant property}

\section{Radical-scavenging ability}

The scavenging ability of stable free radicals such as 1,1diphenyl-2-picrylhydrazyl (DPPH) is a known mechanism for antioxidation. The DPPH assay was carried out in triplicate, according to the method reported by Karioti et al. [32]. Extracts of different concentrations (10, 100 and $1000 \mu \mathrm{g} / \mathrm{ml}$ ) were tested in triplicate for free-radical scavenging activity. The scavenging activity of the extract was compared with ascorbic acid $(1000 \mu \mathrm{g} / \mathrm{ml})$. A blank containing methanol instead of the test sample or ascorbic acid was also included under the same condition. The free radical scavenging activity (RSA) as determined by the decolouration of the DPPH solution was calculated according to the formula:

$$
\operatorname{RSA}(\%)=\left[1-\left(A_{\text {test }} / A_{\text {blank }}\right) \times 100\right]
$$

where $A_{\text {test }}$ is the absorbance of the reaction mixture containing the standard antioxidant or extract, and $A_{\text {blank }}$ is the absorbance of the blank test.

\section{Ferrous ion chelating (FIC) assay}

The FIC activity assay of Singh and Rajini [33] was adopted. Briefly, $0.1 \mathrm{mM} \mathrm{FeSO} 4(0.5 \mathrm{ml})$ was mixed with the extract $(0.5 \mathrm{ml})$ of different concentrations $(10,100$ and $1000 \mu \mathrm{g} / \mathrm{ml})$ in triplicate, followed by adding $0.25 \mathrm{mM}$ ferrozine $(1 \mathrm{ml})$. The reaction mixtures were incubated for $10 \mathrm{~min}$ and the absorbance $(A)$ was measured at $562 \mathrm{~nm}$. Ascorbic acid $(1000 \mu \mathrm{g} / \mathrm{ml})$ was included as the positive control. A blank test containing methanol instead of the test sample or ascorbic acid was also included under the same condition. The ability of extracts to chelate ferrous ions was calculated using the following equation:

$$
\text { Chelating ability }(\%)=\left[\left(A_{\text {blank }}-A_{\text {test }}\right) / A_{\text {blank }}\right] \times 100
$$

where $A_{\text {test }}$ is the absorbance of the reaction mixture containing extract or ascorbic acid and $A_{\text {blank }}$ is the absorbance of the blank test.

\section{Ferric ion reducing antioxidant power (FRAP) assay}

The reducing power of extracts was measured according to the colourimetric method reported by Benzie and Straino [34] with a few modifications. In triplicates, methanolic extract $(150 \mu \mathrm{l})$ of different concentrations at 10,100 or $1000 \mu \mathrm{g} / \mathrm{ml}$ was added to $2850 \mu \mathrm{l}$ of FRAP solution that constituted of $300 \mathrm{mM}$ acetate buffer, $50 \mathrm{ml}$; $10 \mathrm{mM}$ 2,4,6-tripyridyl-s-triazine (TPTZ), $5 \mathrm{ml}$; and $20 \mathrm{mM}$ ferric chloride, $5 \mathrm{ml}$. Following the same procedure, a blank test containing $80 \%$ methanol instead of extract was included, while trolox at $10 \mu \mathrm{g} / \mathrm{ml}$ served as the positive control under the same condition. The reaction mixtures were incubated in the dark for $30 \mathrm{~min}$. The reduction of the $\mathrm{Fe}^{3+}$-TPTZ complex to a coloured $\mathrm{Fe}^{2+}$-TPTZ complex by the extract was monitored by measuring the absorbance at $593 \mathrm{~nm}$ using a Helios Omega UV-vis spectrophotometer (Thermo Scientific technologies, Madison, USA). The changes in absorbance values of test reaction mixtures from the initial blank reading were considered as FRAP activity.

\section{Tyrosinase inhibition property}

Tyrosinase inhibition activity was determined as

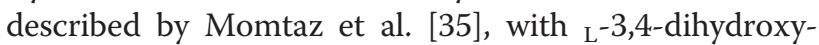
phenylalanine (L-DOPA, Sigma) and tyrosine as substrates. Samples were dissolved in dimethyl sulfoxide (DMSO) to a concentration of $20 \mathrm{mg} / \mathrm{ml}$, and further diluted in potassium phosphate buffer $(50 \mathrm{mM}, \mathrm{pH} 6.5)$ to $600 \mu \mathrm{g} / \mathrm{ml}$. Assays were carried out in a 96-well micro-titre plate and a Multiskan FC plate reader (Thermo scientific technologies, China) was used. All the steps in the assay were conducted at room temperature. In triplicate, each prepared sample $(70 \mu \mathrm{l})$ was mixed with $30 \mu \mathrm{l}$ of tyrosinase (333 Units/ml in phosphate buffer, $\mathrm{pH}$ 6.5). After $5 \mathrm{~min}$ incubation, $110 \mu \mathrm{l}$ of substrate ( $2 \mathrm{mM}_{\mathrm{L}}$-tyrosine or $12 \mathrm{mM} \mathrm{L-DOPA}$ ) was added to the reaction mixtures and incubated further for $30 \mathrm{~min}$. The final concentration of the extract was between $2.6-333.3 \mu \mathrm{g} / \mathrm{ml}$. Arbutin $(1.04-133.33 \mu \mathrm{g} / \mathrm{ml})$ was used as a positive control while a blank test was used as each sample that had all the components except L-tyrosine or ${ }_{\mathrm{L}}$-DOPA. Results were compared with a control consisting of DMSO instead of the test sample. Absorbance values of the wells were then determined at $492 \mathrm{~nm}$. The percentage tyrosinase inhibition was calculated as follows:

$$
\% \text { inhibition }=\left[\left(A_{\text {control }}-A_{\text {sample }}\right) / A_{\text {control }}\right] \times 100
$$

where $A_{\text {control }}$ is the absorbance of DMSO and $A_{\text {sample }}$ is the absorbance of the test reaction mixture containing extract or arbutin. The $\mathrm{IC}_{50}$ values of extracts and arbutin were calculated.

\section{Phenolic content determination Total phenolic content (TPC)}

The total phenolic (TP) content was determined in triplicate by the Folin-Ciocalteu (Folin-C.) colourimetric method [36] as modified by Makkar [37] and calculated as gallic acid equivalents (GAE) per gram DM.

\section{Total flavonoid content (TFC)}

Total flavonoid content (TFC) was determined using the method described by Yang et al. [38] and the results were expressed as catechin equivalent (CAE) per gram DM. 


\section{Rhodanine assay for gallotannin content (GTC)}

Determination of the gallotannin content in peel methanolic extracts was carried out as described by Makkar [37]. Samples $(50 \mu \mathrm{l})$ were mixed with $150 \mu \mathrm{l}$ of $0.4 \mathrm{~N}$ sulphuric acid followed by $600 \mu \mathrm{l}$ rhodanine. After $10 \mathrm{~min}, 200 \mu \mathrm{l}$ of $0.5 \mathrm{~N} \mathrm{KOH}$ were added and subsequently distilled water $(4 \mathrm{ml})$ after $2.5 \mathrm{~min}$. The absorbance was read at $520 \mathrm{~nm}$ (room temperature) against a blank test that contained aqueous methanol instead of the sample after $15 \mathrm{~min}$ incubation. The GTC was calculated from the standard curve (gallic acid) and expressed as gallic acid equivalents (GAE) per gram DM.

\section{Total anthocyanin content (TAC)}

Total anthocyanin content (TAC) was quantified using the $\mathrm{pH}$ differential method described by Wrolstad [39]. In triplicate, each extract $(1 \mathrm{ml})$ was mixed with $9 \mathrm{ml}$ of $\mathrm{pH} 1.0$ and $\mathrm{pH} 4.5$ buffers, in separate test tubes. Absorbance of the reaction mixture was measured at 520 and $700 \mathrm{~nm}$ in $\mathrm{pH} 1.0$ and 4.5 buffers. The total absorbance was calculated from Equation 4, while total anthocyanin content was calculated from Equation 5. The result was expressed as cyanidin 3-glucoside.

$$
A=\left(A_{510}-A_{700}\right)_{\mathrm{pH} 1.0}-\left(A_{510}-A_{700}\right)_{\mathrm{pH} 4}
$$

Total anthocyanin $(\mu \mathrm{g} / \mathrm{ml})=[(A \mathrm{x} \mathrm{MW} \times \mathrm{DF}) / \varepsilon \times \mathrm{L}]$

$A=$ Absorbance, $\varepsilon=$ Cyd-3-glucoside molar absorbance (26,900), MW = anthocyanin molecular weight (449.2), $\mathrm{DF}=$ dilution factor, $\mathrm{L}=$ cell path-length $(1 \mathrm{~cm})$. Final results are expressed as Cyd-3-glucoside equivalent $\left(\mathrm{C}_{3} \mathrm{gE}\right)$ per gram dry matter $\left(\mu \mathrm{g} \mathrm{C}_{3} \mathrm{gE} / \mathrm{g} \mathrm{DM}\right)$.

\section{HPLC-ESI/MS ${ }^{n}$ analysis of phenolic composition}

The LC-MS analysis of phenolics and anthocyanin components in the pomegranate peel extract was performed according to Fischer et al. [40] with slight modification, using a Synapt $G_{2}$ mass spectrometer UPLC ${ }^{\mathrm{TM}}$ system (Waters Corp., Milford, USA) connected to a photo diode array detector and a BEH C18 column $(1.7 \mu \mathrm{m}$ particle size, $2.1 \times 100 \mathrm{~mm}$, Waters Corp.). The mobile phases were $5 \%$ formic acid in water ( $\mathrm{v} / \mathrm{v})$ as eluent $\mathrm{A}$ and $95 \%$ acetonitrile, $5 \%$ formic acid $(\mathrm{v} / \mathrm{v})$ as eluent $\mathrm{B}$. The flow rate was fixed at $0.2 \mathrm{ml} / \mathrm{min}$ and the column temperature was set at $40^{\circ} \mathrm{C}$. The electrospray ionization (ESI) probe was operated in the positive mode with the capillary voltage of $3 \mathrm{kV}$; and cone voltage of $15 \mathrm{~V}$. The injection volume was $10 \mu \mathrm{l}$ and the detection was the diode array detector was set at between 200-600 nm. Individual phenolic compounds were quantified by comparison with a multipoint calibration curve obtained from the corresponding standard (catechin, epicatechin, protocatechuic acid, gallic acid, ellagic acid) from Sigma Aldrich (Germany), while anthocyanins were quantified by an external standard cyanidin 3, 5-diglucoside (Sigma Aldrich, Germany).

\section{Statistical analysis}

All data are presented as mean values $( \pm$ S.E). Analysis of variance (ANOVA) was performed using SPSS 10.0 for Windows (SPSS Inc. Chicago, USA). Where there was statistical significance $(P<0.05)$, the means were further separated using Duncan's Multiple Range Test. Graphical analysis carried out using GraphPad Prism software version 4.03 (GraphPad Software, Inc. San Diego, USA). The $\mathrm{IC}_{50}$ values for the tyrosinase assay were calculated from the logarithmic non-linear regression curve derived from the plotted data using GraphPad Prism software version 4.03 (GraphPad Software, Inc., San Diego, USA).

\section{Results and discussion \\ Antibacterial activity}

Antibacterial activities of methanol and aqueous peel extracts of all the investigated pomegranate cultivars is presented in Table 1. None of the aqueous extracts exhibited good antibacterial activity at the highest screening concentration $(>12.5 \mathrm{mg} / \mathrm{ml})$. The methanol extract, however, showed varying broad-spectrum antibacterial activity at statistically different MIC values $(P<0.05)$ against the test bacteria. Although it is ideal to test plant extracts against a wide range of target microorganisms, taxonomically representative bacterial species were used in this test to avoid handling numerous pathogenic microorganisms. The minimum inhibitory concentrations (MIC) were obtained for extract concentrations ranging from 0.78 to $0.20 \mathrm{mg} / \mathrm{ml}$. In this study, MIC values less than $1.0 \mathrm{mg} / \mathrm{ml}$ were considered active for crude extracts [41]. Similar to the findings reported by Opara et al. [42] on peels of pomegranates grown in Oman, all peel extracts of the investigated fruit cultivars showed activity against the Gram negative and positive bacteria used. These findings are contrary to the work of Kanatt et al. [43], which reported that pomegranate extracts showed little or no effect with regards to Gram negative bacteria. The content of methanol used in the assay was inactive against tested bacteria in the assay. It is worth noting that although $80 \%$ methanol was used to dissolve the extracts, methanol concentration was $<1.25 \%$ in all the extracts where the MIC values were record. The total antibacterial index (TAI) was calculated to determine the overall effects of the peel extracts of each cultivar of pomegranate studied against test bacteria. The most active cultivar was Herskawitz with the highest TAI value (6.25), while the lowest TAI value was exhibited by Bhagwa cultivar; clearly indicating that activity was cultivar dependent. 
Table 1 Antibacterial activity of fruit peel methanol extracts of pomegranate cultivars cultivated in South Africa

\begin{tabular}{|c|c|c|c|c|c|c|}
\hline \multirow[b]{2}{*}{ Cultivar } & \multirow[b]{2}{*}{ Extract } & \multicolumn{4}{|c|}{ Minimum inhibitory concentration (MIC; mg/ml) } & \multirow[b]{2}{*}{ TAI } \\
\hline & & B.s & E.c & K.p & S.a & \\
\hline \multirow[t]{2}{*}{ Arakta } & $\mathrm{MeOH}$ & $0.39^{b}$ & $0.78^{\mathrm{b}}$ & $0.20^{a}$ & $0.39^{b}$ & $6.00^{b}$ \\
\hline & Aqueous & $>12.50$ & $>12.50$ & $>12.50$ & $>12.50$ & $<1.00$ \\
\hline \multirow[t]{2}{*}{ Bhagwa } & $\mathrm{MeOH}$ & $0.39^{b}$ & $0.78^{\mathrm{b}}$ & $0.20^{\mathrm{a}}$ & $0.78^{\mathrm{c}}$ & $5.70^{a}$ \\
\hline & Aqueous & $>12.50$ & $>12.50$ & $>12.50$ & $>12.50$ & $<1.00$ \\
\hline \multirow[t]{2}{*}{ Ganesh } & $\mathrm{MeOH}$ & $0.39^{\mathrm{b}}$ & $0.39^{\mathrm{a}}$ & $0.20^{\mathrm{a}}$ & $0.78^{c}$ & $6.00^{\mathrm{b}}$ \\
\hline & Aqueous & $>12.50$ & $>12.50$ & $>12.50$ & $>12.50$ & $<1.00$ \\
\hline \multirow[t]{2}{*}{ Herskawitz } & $\mathrm{MeOH}$ & $0.20^{\mathrm{a}}$ & $0.39^{\mathrm{a}}$ & $0.20^{\mathrm{a}}$ & $0.78^{c}$ & $6.25^{c}$ \\
\hline & Aqueous & $>12.50$ & $>12.50$ & $>12.50$ & $>12.50$ & $<1.00$ \\
\hline \multirow[t]{2}{*}{ Molla de Elche } & $\mathrm{MeOH}$ & $0.39^{b}$ & $0.78^{b}$ & $0.39^{b}$ & $0.26^{\mathrm{a}}$ & $5.92^{\mathrm{ab}}$ \\
\hline & Aqueous & $>12.50$ & $>12.50$ & $>12.50$ & $>12.50$ & $<1.00$ \\
\hline \multirow[t]{2}{*}{ Ruby } & $\mathrm{MeOH}$ & $0.39^{b}$ & $0.39^{a}$ & $0.39^{b}$ & $0.39^{b}$ & $6.00^{b}$ \\
\hline & Aqueous & $>12.50$ & $>12.50$ & $>12.50$ & $>12.50$ & $<1.00$ \\
\hline \multirow[t]{2}{*}{ Wonderful } & $\mathrm{MeOH}$ & $0.39^{b}$ & $0.59^{\mathrm{ab}}$ & $0.33^{b}$ & $0.39^{b}$ & $5.99^{b}$ \\
\hline & Aqueous & $>12.50$ & $>12.50$ & $>12.50$ & $>12.50$ & $<1.00$ \\
\hline Streptomycin $(\mu \mathrm{g} / \mathrm{ml})$ & & 3.13 & 3.13 & 2.60 & 5.21 & \\
\hline
\end{tabular}

Mean values in the same column followed by different letters (a-c) represent statistical different $(\mathrm{P}<0.05)$ using the Duncan's multiple range test. MIC- Minimum inhibitory concentration, TAI - Total antibacterial index, the higher the TAI the higher antibacterial activity.

Pomegranate peel polyphenols, especially tannins are the major components in the pomegranate peel extract that have been implicated in antimicrobial potential (for example, antiviral, antifungal and antibacterial activities) [44]. Vasconcelos [45] studied the antibacterial activity of methanolic peel extracts of pomegranate cultivars against both Gram negative and positive bacteria strains and reported MIC values ranging from 0.25 to $4.0 \mathrm{mg} / \mathrm{ml}$ against the test bacteria. The author reported a two-fold MIC value against a Gram positive bacterium (S. aureus) than against a Gram negative bacterium (E. coli). It has been suggested that the antimicrobial activity of tannins may be due to the ability of tannin compounds to precipitate proteins, therefore causing leakage of cell membrane of the microorganism [19], and aiding cell lysis which ultimately leads to cell death.

As the peel extracts are complex mixtures of metabolites (Figure 1), it is difficult to pinpoint all the metabolites that are responsible for pharmacological activity. Other researchers have postulated that punicalagin, along with a combination of various phytochemicals, plays a positive role in perceived bacterial inhibition. Considering the broad spectrum antibacterial property exhibited by the methanolic extracts, the fruit peel of the investigated pomegranate cultivars can be considered an effective antibacterial agent. Several reasons may explain varying antibacterial potency of the extracts tested here. Differences in antibacterial activities in the peel extracts may be linked to inter-genetic cultivar variability which is also associated with the inherent chemical composition of the fruit peel. Also, gene-to-biosynthetic modifications are well established in plants as they respond plastically to geo-environmental spatial variation [46]. Secondary metabolites play a key role as defence chemicals for many plants, and so, their accumulation is often dependent on environmental factors. Chemical heterogeneity ultimately leads to differences in the bioactivity of extracts derived from plants growing in different microclimatic areas as these plants face different abiotic and biotic challenges altering gene expression and secondary metabolite synthesis [47].

\section{Antioxidant activity}

Negi and Jayaprakasha [48] extracted antioxidants from pomegranate peel with the use of methanol, acetone or water and found that methanol gave maximum antioxidant yield. In this study, some degree of radical scavenging activity (RSA) was observed in all the evaluated extracts, with considerable increase in RSA with increase in concentration level. Considering RSA of $50 \%$ as good activity, poor RSAs were exhibited by all the evaluated samples at concentrations of $100 \mu \mathrm{g} / \mathrm{ml}$ and $10 \mu \mathrm{g} / \mathrm{ml}$ (Table 2). However at the highest concentration tested $(1000 \mu \mathrm{g} / \mathrm{ml})$, the RSA was superior in all the fruit cultivars. The RSA values were significantly higher in Arakta (83.54\%), Ganesh (83.56\%), and Ruby (83.34\%) cultivars $(p<0.05)$, while the lowest activity was exhibited by the Molla de Elche cultivar (71.65\%). The RSA of ascorbic acid (67.02\%), used in this study as a positive control, was lower than the plant extracts at $1000 \mu \mathrm{g} / \mathrm{ml}$.

The chelating ability of methanolic extracts of pomegranate peel on ferrous ion is presented in Table 2. 


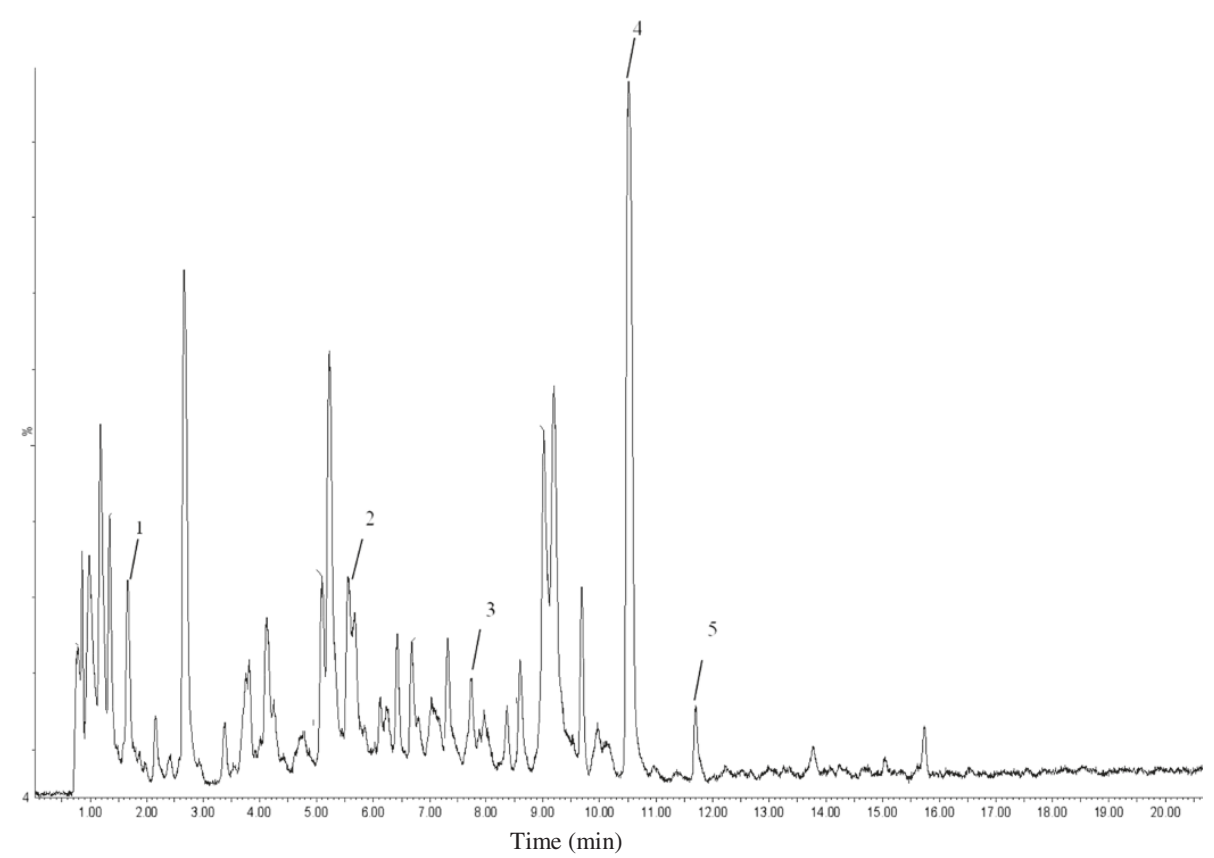

Figure 1 Typical HPLC-MS chromatogram of methanolic peel extract of pomegranate fruit. (1) Gallic acid; (2) Catechin; (3) Epicatechin; (4) Ellagic acid; (5) Rutin.

Similar to the RSA results, the ferrous ion chelating (FIC) activity of methanolic peel extract exhibited a linear exponential relationship with extract concentration. Although low FIC activity was exhibited at the lowest concentration $(10 \mu \mathrm{g} / \mathrm{ml})$ assayed, extracts of Molla de Elche, Ruby and Wonderful showed relatively good FIC activity, ranging from 47.24 to $49.65 \%$. At $100 \mu \mathrm{g} / \mathrm{ml}$ the FIC activity of all extracts (except Arakta cultivar) increased above 50\%, with Herskawitz, Molla de Elche and Wonderful, showing highest values of 69.97\%, $70.57 \%$ and $71.02 \%$, respectively. Moreover, FIC activity exhibited by methanolic extracts of most of the investigated at $100 \mu \mathrm{g} / \mathrm{ml}$ were higher than that of the positive control (ascorbic acid at $1000 \mu \mathrm{g} / \mathrm{ml}$ ). Dose dependent
FIC activity exhibited by all the investigated extracts indicate that the pomegranate fruit peel contains constituents that inhibit oxidation through a mechanism other than radical scavenging activity.

The FRAP assay measures the ability of an antioxidant to reduce ferric (III) to ferrous (II) in a redox-linked colourimetric reaction that involves single electron transfer [12]. The reducing power of a compound serves as a significant indicator of its potential antioxidant activity. All the investigated extracts showed dose-dependent reducing power (Table 2). Interestingly, there was no significant difference $(p<0.05)$ in the reducing capacities among all the cultivars at the highest concentration $(1000 \mu \mathrm{g} / \mathrm{ml})$.

Table 2 Antioxidant activity of fruit peel methanol extracts of seven pomegranate cultivars cultivated in South Africa

\begin{tabular}{|c|c|c|c|c|c|c|c|c|c|}
\hline \multirow[b]{2}{*}{ Cultivar } & \multicolumn{3}{|c|}{ DPPH (\%) } & \multicolumn{3}{|c|}{ FIC (\%) } & \multicolumn{3}{|c|}{ FRAP (abs. at $593 \mathrm{~nm}$ ) } \\
\hline & $1000 \mu \mathrm{g} / \mathrm{ml}$ & $100 \mu \mathrm{g} / \mathrm{ml}$ & $10 \mu \mathrm{g} / \mathrm{ml}$ & $1000 \mu \mathrm{g} / \mathrm{ml}$ & $100 \mu \mathrm{g} / \mathrm{ml}$ & $10 \mu \mathrm{g} / \mathrm{ml}$ & $1000 \mu \mathrm{g} / \mathrm{ml}$ & $100 \mu \mathrm{g} / \mathrm{ml}$ & $10 \mu \mathrm{g} / \mathrm{ml}$ \\
\hline Arakta & $83.54 \pm 0.31^{d}$ & $13.35 \pm 0.98^{\mathrm{ab}}$ & $5.55 \pm 0.06^{c}$ & $79.44 \pm 0.21^{\mathrm{a}}$ & $49.94 \pm 0.89^{a}$ & $37.32 \pm 1.82^{b}$ & $1.19 \pm 0.03^{\text {ns }}$ & $0.52 \pm 0.02^{b}$ & $0.11 \pm 0.00^{c}$ \\
\hline Bhagwa & $73.02 \pm 0.26^{\mathrm{ab}}$ & $12.34 \pm 0.73^{\mathrm{ab}}$ & $1.37 \pm 0.34^{\mathrm{a}}$ & $84.96 \pm 1.43^{b c}$ & $65.54 \pm 1.09^{c}$ & $18.83 \pm 0.22^{\mathrm{a}}$ & $1.03 \pm 0.28$ & $0.38 \pm 0.00^{\mathrm{ab}}$ & $0.04 \pm 0.01^{\mathrm{a}}$ \\
\hline Ganesh & $83.56 \pm 0.05^{d}$ & $16.70 \pm 0.83^{b c}$ & $2.42 \pm 0.99^{\mathrm{ab}}$ & $82.98 \pm 0.18^{b}$ & $65.82 \pm 0.51^{c}$ & $15.80 \pm 0.52^{\mathrm{a}}$ & $1.47 \pm 0.04$ & $0.73 \pm 0.12^{c}$ & $0.08 \pm 0.01^{b c}$ \\
\hline Herskawitz & $78.06 \pm 0.71^{c}$ & $15.18 \pm 0.97^{\mathrm{abc}}$ & $2.71 \pm 0.77^{\mathrm{ab}}$ & $87.82 \pm 0.57^{\text {de }}$ & $69.97 \pm 0.25^{d}$ & $34.32 \pm 2.45^{b}$ & $1.29 \pm 0.04$ & $0.34 \pm 0.01^{\mathrm{ab}}$ & $0.08 \pm 0.02^{b c}$ \\
\hline Molla de Elche & $71.65 \pm 0.08^{\mathrm{a}}$ & $10.59 \pm 0.18^{\mathrm{a}}$ & $1.61 \pm 0.08^{\mathrm{a}}$ & $86.59 \pm 0.90^{c d}$ & $70.57 \pm 0.43^{d}$ & $47.24 \pm 1.34^{c}$ & $1.47 \pm 0.11$ & $0.33 \pm 0.05^{\mathrm{a}}$ & $0.03 \pm 0.00^{\mathrm{a}}$ \\
\hline Ruby & $83.34 \pm 0.51^{d}$ & $19.67 \pm 2.24^{c}$ & $4.10 \pm 2.24^{b c}$ & $83.58 \pm 0.62^{b}$ & $53.39 \pm 1.29^{b}$ & $47.25 \pm 0.66^{c}$ & $1.18 \pm 0.02$ & $0.38 \pm 0.00^{\mathrm{ab}}$ & $0.08 \pm 0.01^{b c}$ \\
\hline Wonderful & $74.19 \pm 1.05^{\mathrm{b}}$ & $12.22 \pm 3.13^{\mathrm{ab}}$ & $3.01 \pm 0.47^{\mathrm{ab}}$ & $89.67 \pm 0.72^{e}$ & $71.02 \pm 0.38^{d}$ & $49.65 \pm 1.26^{c}$ & $1.32 \pm 0.16$ & $0.33 \pm 0.01^{a}$ & $0.06 \pm 0.00^{\mathrm{ab}}$ \\
\hline Ascorbic acid & $67.02 \pm 0.06$ & & & $62.15 \pm 0.98$ & & & & & \\
\hline
\end{tabular}

Trolox 
Antioxidant capacity based on both the free radical scavenging and the oxidation-reduction mechanisms may be determined by several methods, although the mechanism of action set in motion by antioxidant compounds is still not clearly understood [26]. Previous studies have shown strong antioxidant activity in pomegranate fruit peel extracts $[12,13]$. In comparison with other fruit peels, Okonogi et al. [49] studied the radical scavenging activity on DPPH and ABTS of pomegranate peel extract with other fruit types including rambutan, mangosteen, banana, coconut, dragon fruit, passion fruit as well as long-gong fruit. In the study the highest scavenging activity was reported in pomegranate peel extract. The observed antioxidant property in the peel extract in this study could be attributed to polyphenol compounds such as ellagic tannins, ellagic acid and gallic acid $[24,50]$. The results show that pomegranate peel may have great relevance in the prevention and therapies of diseases in which oxidants or free radicals are implicated, hence could serve as an economic source of natural antioxidants.

\section{Tyrosinase inhibition activity}

Tyrosinase inhibitors are chemical agents capable of reducing enzymatic reactions such as food browning and melanisation of human skin [23]. Results of tyrosinase inhibition activity of pomegranate methanol peel extract at different concentration $(2.6-333.3 \mu \mathrm{g} / \mathrm{ml})$ are presented in Figure $2 \mathrm{~A}$ and $\mathrm{B}$ against monophenolase (tyrosine) and diphenolase (DOPA), respectively, and activities were assessed in terms of dopachrome formation. Although the extracts were initially dissolved in $100 \%$ DMSO, the final content of the DMSO in the reaction mixture was between $0.14 \%$ and $18.3 \%$. Also, DMSO was used as a control in the assay therefore the effect of DMSO (if any) would have been taken


Figure 2 Tyrosinase enzyme inhibitory activity of fruit peel methanol extracts of seven pomegranate cultivars cultivated in South Africa. Monophenolase inhibition (A) and Diphenolase inhibition (B). 
care of in the calculation. Generally, tyrosinase inhibition was displayed in a dose-dependent way and there was higher monophenolase inhibition than diphenolase inhibition. In this study, inhibition activity percentage above $50 \%$ was described as good tyrosinase inhibition. All extracts exhibited good inhibition against monophenolase and diphenolase activities at the highest screening concentration (Figure 2). Furthermore, there were significant $(p<0.05)$ differences in the concentrations of $50 \%$ tyrosinase inhibition $\left(\mathrm{IC}_{50}\right)$ by the fruit peel. The most active peel extract was the Bhagwa cultivar against monophenolase and the Arakta cultivar against diphenolase with $\mathrm{IC}_{50}$ values of $3.66 \mu \mathrm{g} / \mathrm{ml}$ and $15.88 \mu \mathrm{g} / \mathrm{ml}$, respectively (Table 3 ). The inhibitory activities of most of the peel extracts were higher than the positive control (arbutin) which is a known tyrosinase inhibitor. The $\mathrm{IC}_{50}$ values obtained in this study were higher than those reported by Yoshimura et al. [23] where $\mathrm{IC}_{50}$ value of $182.2 \mu \mathrm{g} / \mathrm{ml}$ was reported for $50 \%$ aqueous ethyl alcohol extract of pomegranate rind. Polyphenols are also the largest groups in tyrosinase inhibitors until now [51]. The pomegranate fruit peel is rich in polar substances such as polyphenol such as flavonoid constituents and tannins. In solution, the defining characteristic of tannins is the ability to precipitate mainly proteins, and the structure of flavonoid is compatible with the roles of both substrates and inhibitors of tyrosinase [51]. It could be suggested that tannin content in pomegranate peel could precipitate tyrosinase enzyme, thereby inhibiting enzymatic activity in the reaction medium. These constituents are readily soluble in methanol and show high tyrosinase inhibitory activity in different plants [52,53].

According to Yoshimura et al. [23], ellagic acid in pomegranate rind showed an inhibitory effect on tyrosinase in vitro and a whitening effect in vivo on UVinduced pigmentation of brownish guinea pig skin. On

Table 3 Effective inhibition concentration $\left(E C_{50}\right)$ of fruit peel methanol extracts against tyrosinase

\begin{tabular}{|c|c|c|}
\hline Cultivar & $\begin{array}{c}\mathrm{IC}_{50} \begin{array}{c}\text { Monophenolase } \\
(\mu \mathrm{g} / \mathrm{ml})\end{array} \\
\end{array}$ & $\begin{array}{c}\mathrm{IC}_{50} \begin{array}{c}\text { Diphenolase } \\
(\mu \mathrm{g} / \mathrm{ml})\end{array} \\
\end{array}$ \\
\hline Arakta & $11.03 \pm 0.08^{c}$ & $15.88 \pm 0.10^{\mathrm{a}}$ \\
\hline Bhagwa & $3.66 \pm 0.11^{\mathrm{a}}$ & $21.16 \pm 0.09^{a}$ \\
\hline Ganesh & $25.38 \pm 0.06^{f}$ & $40.93 \pm 0.12^{b}$ \\
\hline Herskawitz & $7.56 \pm 0.08^{b}$ & $59.03 \pm 0.07^{c}$ \\
\hline Molla de Elche & $25.56 \pm 0.06^{f}$ & $27.11 \pm 0.09^{\mathrm{ab}}$ \\
\hline Ruby & $20.33 \pm 0.07^{d}$ & $114.9 \pm 0.08^{\mathrm{e}}$ \\
\hline Wonderful & $23.67 \pm 0.06^{\mathrm{e}}$ & $27.26 \pm 0.07^{\mathrm{ab}}$ \\
\hline Arbutin & $34.66 \pm 0.05^{9}$ & $98.66 \pm 0.12^{d}$ \\
\hline
\end{tabular}

Mean values in the same column followed by different letters (a-f) represent statistical different $(P<0.05)$ using the Duncan's multiple range test. the contrary, however, Chang [51] argued that some phenolic compounds could be mistakenly classified as tyrosinase inhibitors due to their role as alternative enzyme substrates whose quinoid reaction products absorb in a spectral range different from that of dopachrome. As a result, when the phenolics show a good affinity for the enzyme, dopachrome formation is prevented.

\section{Phenolic compounds analysis \\ Total phenolics, flavonoid, gallotannin and anthocyanin}

Pomegranate fruit components are rich in phenolic compounds which have synergistic and/or additive effects on its pharmacological properties [22]. Phenolic constituents in pomegranate peel have been implicated in bioactivities such as antimicrobial, antioxidant, and anti-tyrosinase activities $[23,24,44]$. Results obtained in this study revealed significant cultivar differences $(p<0.05)$ in the levels of phenolic compounds (Table 4). The Ganesh cultivar had the highest amount of total phenolics $(295.5 \mathrm{mg} / \mathrm{g} \mathrm{DM})$ whereas Molla de Elche cultivar had the lowest phenolic contents $(179.3 \mathrm{mg} / \mathrm{g} \mathrm{DM})$. These results corroborate the levels of total phenolic content $(249.4 \mathrm{mg} / \mathrm{g})$ reported by Li et al. [12], who also found that total phenolic content of pomegranate peel extract was 10 -fold as high as that of the juice extract. Similarly, the highest (126 mg/g DM) and lowest $(97.8 \mathrm{mg} / \mathrm{g} \mathrm{DM})$ contents of total flavonoid were measured in Ruby and Wonderful cultivars, respectively. This result was expected as flavonoid is a major phenolic group in pomegranate and should contribute to the total phenolic content in the peel extracts. Flavonoid contents found in the investigated cultivars were higher than the value reported by $\mathrm{Li}$ et al. [12]. Although the gallotannin content in Arakta $(783.6 \mu \mathrm{g} / \mathrm{g}$ DM) was insignificantly higher than that of Ganesh $(777.2 \mu \mathrm{g} / \mathrm{g}$ DM) the cultivar contained higher amount of gallotannin than in other cultivars. Anthocyanin is one of the most important groups of flavonoid which is responsible for red colouration of pomegranate fruit [54]. Total anthocyanin was the highest in Wonderful $(322.2 \mu \mathrm{g} / \mathrm{g}$ DM) whereas the lowest was contained in the Molla de Elche cultivar $(58.5 \mu \mathrm{g} / \mathrm{g} \mathrm{DM})$.

\section{HPLC-MS ${ }^{n}$ analysis of phenolic composition}

Individual phenolic compounds in pomegranate fruit peel such as punicalagin, ellagic acid, gallic acid, caffeic acid, protocatechuic acid and p-coumaric acid have received considerable attention due to their potent antibacterial, antioxidant and anti-tyrosinase activities [22,24,44,50,55,56]. High-performance liquid chromatography-mass spectrometry (HPLC-MS) was used to determine the individual concentrations of the most prominent phenolic compounds in the methanolic peel extract of pomegranate cultivars studied. As shown in Figure 3, seven individual phenolics were identified and quantified, 
Table 4 Phenolic contents in fruit peel methanol extracts of seven pomegranate cultivars cultivated in South Africa

\begin{tabular}{|c|c|c|c|c|}
\hline \multirow[t]{2}{*}{ Cultivar } & Total phenolics & Total flavonoid & Total gallotannin & Total anthocyanin \\
\hline & $\overline{\mathrm{mg} \mathrm{GAE} / \mathrm{g} \mathrm{DM}}$ & $\overline{\mathrm{mg} \mathrm{CAE} / \mathrm{g} \mathrm{DM}}$ & $\mu \mathrm{g} \mathrm{GAE} / \mathrm{g} \mathrm{DM}$ & $\mu \mathrm{g} \mathrm{C} \mathrm{C}_{3} \mathrm{gE} / \mathrm{g} \mathrm{DM}$ \\
\hline Arakta & $187.4 \pm 6.44^{\mathrm{ab}}$ & $103.0 \pm 1.86^{\mathrm{a}}$ & $783.6 \pm 65.11^{d}$ & $289.7 \pm 1.63^{d}$ \\
\hline Bhagwa & $224.1 \pm 6.86^{c}$ & $112.6 \pm 1.51^{b}$ & $697.7 \pm 42.92^{c d}$ & $312.6 \pm 1.25^{\mathrm{e}}$ \\
\hline Ganesh & $295.5 \pm 23.91^{d}$ & $121.1 \pm 3.12^{c}$ & $777.2 \pm 34.28^{d}$ & $65.1 \pm 1.00^{\mathrm{a}}$ \\
\hline Herskawitz & $198.1 \pm 9.22^{\mathrm{abc}}$ & $101.0 \pm 1.02^{\mathrm{a}}$ & $530.1 \pm 33.86^{\mathrm{b}}$ & $195.9 \pm 2.25^{c}$ \\
\hline Molla de Elche & $179.3 \pm 4.60^{\mathrm{a}}$ & $99.5 \pm 2.94^{a}$ & $560.3 \pm 62.08^{b c}$ & $58.5 \pm 1.27^{\mathrm{a}}$ \\
\hline Ruby & $218.2 \pm 4.53^{\mathrm{bc}}$ & $126.0 \pm 0.57^{c}$ & $326.0 \pm 35.28^{a}$ & $111.7 \pm 3.51^{b}$ \\
\hline Wonderful & $189.1 \pm 3.79^{\mathrm{ab}}$ & $97.8 \pm 2.10^{\mathrm{a}}$ & $466.3 \pm 69.4^{\mathrm{ab}}$ & $322.2 \pm 11.90^{f}$ \\
\hline
\end{tabular}

$G A E$, gallic acid equivalent; $C A E$, catechin equivalent; $C_{3} g E$, cyanidin-3glucoside equivalent; $D M$, dry mass. Mean values in the same column followed by different letters $(\mathrm{a}-\mathrm{c})$ represent statistical different $(\mathrm{P}<0.05)$ using the Duncan's multiple range test.

namely; anthocyanins: delphinidin 3,5-diglucoside, cyanidin 3,5-diglucoside flavonoids: catechin, epicatechin and rutin; hydrolysable tannin: ellagic acid; and hydroxybenzoic acid: gallic acid. Phenolic profile and concentration varied amongst the fruit cultivars. Catechin, epicatechin, ellagic acid and gallic acid were found in all cultivars, of which ellagic acid was the most abundant comprising of more than $50 \%$ of total phenolic compounds detected in each cultivar. The concentration of ellagic acid ranged from $46.87 \mu \mathrm{g} / \mathrm{ml}$ (Ruby) to $209.44 \mu \mathrm{g} / \mathrm{ml}$ (Ganesh). The anthocyanin types; delphinidin 3,5- diglucoside and cyanidin 3,5- diglucoside, were detected in Arakta, Bhagwa and Herskawitz cultivars, while Ganesh, Ruby and Wonderful cultivars contained only cyanidin 3,5- diglucoside (Figure 3).

Noda et al. [57] reported that cyanidin, pelargonidin, and delphinidin were the principal anthocyanins in pomegranate peel. In the present study, Rutin was found in all cultivars except in Wonderful cultivar, and catechin was the highest in Molla de Elche cultivar with a concentration of $28.85 \mu \mathrm{g} / \mathrm{ml}$. Overall, the total concentration of the identified phenolic compounds was in the order of Ganesh > Herskawitz $>$ Molla de Elche $>$ Bhagwa $>$ Arakta $>$ Wonderful $>$ Ruby. The presence of these polyphenols in the pomegranate peel may be responsible for the bioactivities observed in the methanol extracts. Phenolic types

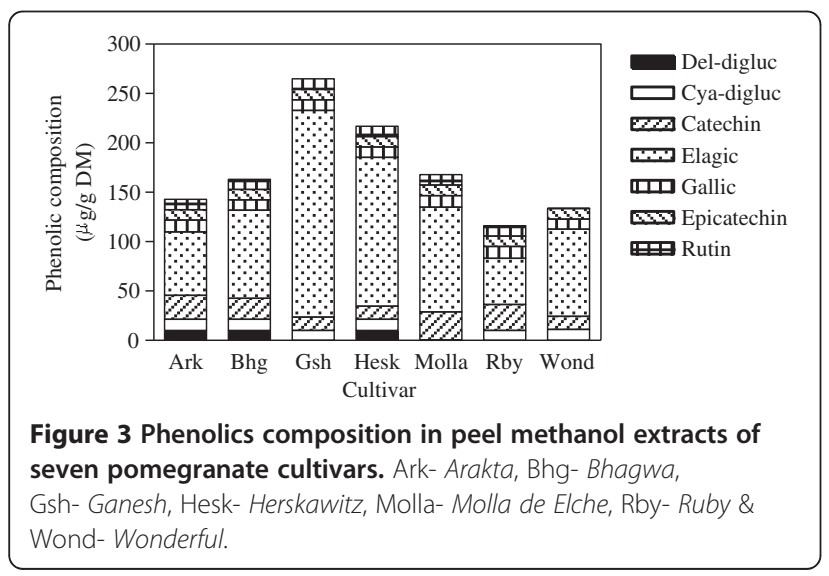

contained in plants influence antimicrobial activity of the plants [58]. For instance, flavone, quercetin and naringenin were reported showing strong inhibitory activity on the growth of Aspergillus niger, Bacillus subtilis, Candida albicans, Escherichia coli, Micrococcus luteus, Pseudomonas aeruginosa, Saccharomyces cerevisiae, Staphylococcus aureus and Staphylococcus epidermidis, while gallic acid inhibited only $P$. Aeruginosa whereas no inhibitory activity was exhibited by rutin and catechin on the tested microorganisms [58]. Major chemicals identified through LCMS may not be the only compounds responsible for bioactivity in the pomegranate peel extracts. Other compounds not identified may play a more significant role in the biological activities exhibited by the peel extracts.

\section{Conclusion}

This study has shown that the peel of the investigated pomegranate fruit cultivars possess strong antibacterial, antioxidant and anti-tyrosinase activities. Therefore the peel of the pomegranate fruit cultivars, instead of being wasted, could be exploited as a potential source of natural antimicrobial and antioxidant agents, as well as a potential tyrosinase inhibitor. The findings provide scientific basis to promote value-adding of pomegranate fruit peels for pharmaceutical and cosmetic purposes. Further studies on the isolation of active ingredients, determination of cytotoxicity and genotoxicity effects as well as the mode of action of tyrosinase-inhibitory, antibacterial and antioxidant properties in pomegranate peel extracts are warranted.

\section{Competing interests}

The authors declare that they have no competing interests.

\section{Authors' contributions}

OAF was involved in sample collection, carried out the antibacterial, antioxidant and tyrosinase assays as well as statistical analysis, and also drafted the manuscript. NPM was heavily involved in the antibacterial assay as well as phytochemical and HPLC-MS analyses, and was also mainly involved in scientific correction of the draft manuscript. ULO designed and supervised the study, and revised the manuscript for critically important content. All authors approved the final manuscript. 


\section{Acknowledgments}

This work is based upon research supported by the South African Research Chairs Initiative of the Department of Science and Technology and National Research Foundation (Pretoria). The authors are grateful to Citrogold Ltd South Africa and Perishable Products Export Control Board (PPECB) for their financial support. Dr M Stander (Central Analytical Facility, Stellenbosch University) is thanked for her assistance with HPLC-MS analysis. The authors acknowledge the input of the Division of Research Development (Subcommittee B) at Stellenbosch University.

\section{Author details}

${ }^{1}$ Postharvest Technology Research Laboratory, South African Research Chair in Postharvest Technology, Faculty of AgriSciences, Stellenbosch University, Private Bag X1, Stellenbosch 7602, South Africa. ${ }^{2}$ Department of Botany and Zoology, Faculty of Science, Stellenbosch University, Private Bag X1, Stellenbosch 7602, South Africa.

Received: 5 June 2012 Accepted: 3 October 2012

Published: 30 October 2012

\section{References}

1. Lampe JW: Health effects of vegetables and fruits: assessing mechanism of action in human experimental studies. Am J Clin Nutr 1999, 70:475-490.

2. Wong SP, Leong LP, Koh JHW: Antioxidant activities of aqueous extracts of selected plants. Food Chem 2006, 99:775-783.

3. Naczk M, Shahidi F: Phenolics in cereals, fruits and vegetables: Occurrence, extraction and analysis. J Pharm Biomed Anal 2006, 41:1523-1542.

4. Abdel-Hameed ESS: Total phenolic contents and free radical scavenging activity of certain Egyptian Ficus species leaf samples. Food Chem 2009, 114:1271-1277.

5. Cai Y, Luo Q, Sun M, Corke H: Antioxidant activity and phenolic compounds of 112 Chinese medicinal plants associated with anticancer. Life Sci 2004, 74:2157-2184.

6. Hazra B, Sarkar R, Biswas S, Mandal N: Comparative study of the antioxidant and reactive oxygen species scavenging properties in the extracts of the fruits of Terminalia chebula, Terminalia belerica and Emblica officinalis. BMC Complement Altern Med 2010, 10:20.

7. Hazra B, Biswas S, Mandal N: Antioxidant and free radical scavenging activity of Spondias pinnata. BMC Complement Altern Med 2008, 8:63.

8. Opara UL, Al-Ani MR: Antioxidant contents of pre-packed fresh-cut versus whole fruit and vegetables. Br Food J 2010, 112:797-810.

9. Martınez JJ, Melgarejo P, Hernandez F, Salazar DM, Martınez R: Seed characterization of five new pomegranate varieties. Sci Hort 2006, 110:241-246.

10. Jaiswal V, DerMarderosian A, Porter JR: Anthocyanins and polyphenol oxidase from dried arils of pomegranate (Punica granatum L.). Food Chem 2010, 118:11-16.

11. Al-Said FA, Opara LU, Al-Yahyai RA: Physico-chemical and textural quality attributes of pomegranate cultivars (Punica granatum L.) grown in the Sultanate of Oman. J Food Eng 2009, 90:129-134.

12. Li Y, Guo C, Yang J, Wei J, Xu J, Cheng S: Evaluation of antioxidant properties of pomegranate peel extract in comparison with pomegranate pulp extract. Food Chem 2006, 96:254-260.

13. Hajimahmoodi M, Oveisi MR, Sadeghi N, Jannat B, Hajibabi M, Farahani E, Akrami MR, Namdar R: Antioxidant properties of peel and pulp hydro extract in ten Persian pomegranate cultivars. Pak J Biol Sci 2008, 11:16001604.

14. Gözlekçi \$̧, Saraçoğlu O, Onursal E, Özgen M: Total phenolic distribution of juice, peel, and seed extracts of four pomegranate cultivars. Phcog Mag 2011, 7:161-164

15. Ackland ML, Van DeWaarsenburg S, Jones R: Synergistic antiproliferative action of the flavonols quercetin and kaempferol in cultured human cancer cell lines. In Vivo 2005, 19:69-76.

16. Kowalski I, Samojedny A, Paul M, Pietsz G, Wilczok T: Effect of kaempferol on the production and gene expression of monocyte chemoattractant protein-1 in $\mathrm{J7742}$ macrophages. Pharmacol Rep 2005, 57:107-112.

17. Brusselmans K, Vrolix R, Verhoeven G, Swinnen JV: Induction of cancer cell apoptosis by flavonoids is associated with their ability to inhibit fatty acid synthase activity. J Biol Chem 2005, 280:5636-5645.

18. McCarrell EM, Gould SWJ, Fielder MD, Kelly AF, El-Sankary W, Naughton DP: Antimicrobial activities of pomegranate rind extracts: enhancement by addition of metal salts and vitamin C. BMC Complement Altern Med 2008, 8:64.

19. Endo EH, Cortéz DAG, Ueda-Nakamura T, Nakamura CV, Filho BPD: Potent antifungal activity of extracts and pure compound isolated from pomegranate peels and synergism with fluconazole against Candida albicans. Res Microbiol 2010, 161:534-540.

20. Olapour S, Mousavi E, Sheikhzade M, Hoseininezhad O, Najafzadeh H: Evaluation anti-diarrheal effects of pomegranate peel extract. J Iran Chem Soc 2009, 6:115-143.

21. Lin CC, Hsu YF, Lin TC: Effects of punicalagin on arrageenan-induced inflammation in rats. Am J Chinese Med 1999, 27:371-376.

22. Seeram NP, Adams LS, Henning SM, Niu Y, Zhang Y, Nair MG, Heber D: In vitro anti-proliferative, apoptotic and antioxidant activities of punicalagin, ellagic acid and a total pomegranate tannin extract are enhanced in combination with other polyphenols as found in pomegranate juice. J Nutr Biochem 2005, 16:360-367.

23. Yoshimura M, Watanabe $Y$, Kasai K, Yamakoshi J, Koga T: Inhibitory effect of an ellagic acid-rich pomegranate extracts on tyrosinase activity and ultraviolet-induced pigmentation. Biosci, Biotechnol, Biochem 2005, 69:2368-2373

24. Lansky EP, Newman RA: Punica granatum (pomegranate) and its potential for prevention and treatment of inflammation and cancer. $J$ Ethnopharmacol 2007, 109:177-206.

25. Althunibat OY, Al-Mustafa AH, Tarawneh K, Khleifat KM, Ridzwan BH, Qaralleh HN: Protective role of Punica granatum $\mathrm{L}$ peel extract against oxidative damage in experimental diabetic rats. Process Biochem 2010, 45:581-585.

26. Viuda-Martos M, Fernandez-Lopez J, Perez-Alvarez JA: Pomegranate and its many functional components as related to human health: A Review. Compr Rev Food Sci 2010, 9:635-654.

27. Holland D, Hatib K, Bar-Ya'akov I: Pomegranate: botany, horticulture, breeding. Horticultural Reviews 2009, 35:127-191

28. Fawole OA, Opara UL, Theron Kl: Chemical and phytochemical properties and antioxidant activities of three pomegranate cultivars grown in South Africa. Food Bioprocess Tech 2012, 5:425-444

29. Al-Zoreky NS: Antimicrobial activity of pomegranate (Punica granatum L.) fruit peels. Int J Food Microbio/ 2009, 134:244-248.

30. Eloff JN: A sensitive and quick microplate method to determine the minimal inhibitory concentration of plant extracts for bacteria. Planta Med 1998, 64:711-713.

31. Fawole OA, Finnie JF, Van Staden J: Antimicrobial activity and mutagenic effects of twelve traditional medicinal plants used to treat ailments related to the gastro-intestinal tract in South Africa. S Afr J Bot 2009, 75:356-362.

32. Karioti A, Hadjipavlou-Litina D, Mensah MLK, Fleischer TC, Saltsa H: Composition and antioxidant activity of the essential oils of Xylopia aethiopica (Dun) A. Rich. (Annonaceae) leaves stem bark, root bark, and fresh and dried fruits, growing in Ghana. J Agric Food Chem 2004, 52:8094-8098

33. Singh N, Rajini PS: Free radical scavenging activity of an aqueous extract of potato peel. Food Chem 2004, 85:611-616.

34. Benzie IFF, Strain JJ: The ferric reducing ability of plasma (FRAP) as a measure of "antioxidant power" The FRAP assay. Anal Biochem 1996, 239:70-76.

35. Momtaz S, Mapunya BM, Houghton PJ, Edgerly C, Hussein A, Naidoo S, Lall $\mathrm{N}$ : Tyrosinase inhibition by extracts and constituents of Sideroxylon inerme L Stem bark, used in South Africa for skin lightening. J Ethnopharmacol 2008, 119:507-512.

36. Singleton VL, Rossi JA Jr: Colorimetry of total phenolics with phosphomolibdic phosphotungtic acid reagents. Am J Enol Viticult 1965 16:144-158

37. Makkar HPS: Quantification of tannins in tree foliage: A laboratory manual for the FAO/IAEA coordinated research project on 'Use of nuclear and related techniques to develop simple tannin assay for predicting and improving the safety and efficiency of feeding ruminants on the tanniniferous tree foliage' Joint FAO/IAEA division of nuclear techniques in food and agriculture, Vienna, Austria.; 2000.

38. Yang J, Martinson TE, Liu RH: Phytochemical profiles and antioxidant activities of wine grapes. Food Chem 2009, 116:332-339. 
39. Wrolstad RE: Agricultural experiment station: Oregon State University, Station Bulletin. Color and Pigment Analyses in Fruit Products 1993, 624:14-15.

40. Fischer UA, Carle R, Kammerer DR: Identification and quantification of phenolic compounds from pomegranate (Punica granatum L.) peel, mesocarp, aril and differently produced juices by HPLC-DAD-ESI/MS ${ }^{n}$. Food Chem 2011, 127:807-821.

41. Van Vuuren SF: Antimicrobial activity of South African medicinal plants. J Ethnopharmacol 2008, 119:462-472.

42. Opara LU, Al-Ani MR, Al-Shuaibi Y: Physico-chemical Properties, Vitamin C content, and antimicrobial properties of pomegranate fruit (Punica granatum L.). Food Bioprocess Tech 2009, 2:315-321.

43. Kanatt SR, Chander R, Sharma A: Antioxidant and antimicrobial activity of pomegranate peel extract improves the shelf life of chicken products. Int J Food Sci Tech 2010, 45:216-222.

44. Miguel MG, Neves MA, Antunes MD: Pomegranate (Punica granatum L.): A medicinal plant with myriad biological properties - A short review. J Med Plants Res 2010, 4:2836-2847.

45. Vasconcelos NS: Antimicrobial activity of pomegranate (Punica granatum L.) fruit peels. Int J Food Microbiol 2009, 134:244-248,

46. Viljoen AM, Subramoney S, Van Vuuren SF, Baser KHC, Demicri B: The composition, geographical variation and antimicrobial activity of Lippia javanica. Verbenaceae leaf essential oils. J Ethnopharmacol 2005, 96:271-277.

47. Field KJ, Lake JA: Environmental metabolomics links genotype to phenotype and predicts genotype abundance in wild plant populations. Physiol Plant 2011, 142:352-360.

48. Negi PS, Jayaprakasha GK: Antioxidant and antibacterial activities of Punica granatum peel extracts. J Food Sci 2006, 68:1473-1477.

49. Okonogi S, Duangrat C, Anuchpreeda S, Tachakittirungrod S, Chowwanapoonpohn S: Comparison of antioxidant capacities and cytotoxicities of certain fruit peels. Food Chem 2007, 103:839-846.

50. Gil MI, Tomas-Barberan FA, Hess-Pierce B, Holcroft DM, Kader AAL: Antioxidant activity of pomegranate juice and its relationship with phenolic composition and processing. Agric Food Chem 2000, 48:4581-4589.

51. Chang T-S: An updated review of tyrosinase inhibitors. Int J Mol Sci 2009 , 10:2440-2475.

52. Kubo I, Kinst-Hori I, Kubo Y, Yamagiwa Y, Kamikawa T, Haraguchi H: Molecular design of antibrowning agents. J Agric Food Chem 2000, 48:1393-1399.

53. Meda A, Lamien CE, Romito M, Millogo J, Nacoulma OG: Determination of the total phenolic, flavonoid and proline Contents in Burkina Fasan Honey, as well as their radical scavenging activity. Food Chem 2005, 91:571.

54. Afaq F, Saleem M, Krueger CG, Reed JD, Mukhtar H: Anthocyanin and hydrolyzable tannin-rich pomegranate fruit extract modulates MAPK and NF-kappa B pathways and inhibits skin tumorigenesis in CD-1 mice. Int J Cancer 2005, 113:423-433.

55. Duman AD, Ozgen M, Dayisoylu KS, Erbil N, Durgac C: Antimicrobial activity of six pomegranate (Punica granatum L.) varieties and their relation to some of their pomological and phytonutrient characteristics. Molecules 2009, 14:1808-1817.

56. He L, Xu H, Liu X, He W, Yuan F, Hou Z, Gao Y: Identification of phenolic compounds from pomegranate (Punica granatum L.) seed residues and investigation into their antioxidant capacities by HPLC-ABTS+ assay. Food Res Int 2011, 44:1161-1167.

57. Noda Y, Kaneyuki T, Mori A, Packer L: Antioxidant activities of pomegranate fruit extract and its anthocyanidins: delphinidin, cyanidin, and pelargonidin. Agric Food Chem 2002, 50:166-171.

58. Rauha J, Remes S, Heinonen M, Hopia A, Kähkönen M, Kujala T, Pihlaja K, Vuorela H, Vuorela P: Antimicrobial effects of Finnish plant extracts containing flavonoids and other phenolic compounds. Int J Food Microbiol 2000, 56:3-12.

doi:10.1186/1472-6882-12-200

Cite this article as: Fawole et al: Antibacterial, antioxidant and tyrosinase-inhibition activities of pomegranate fruit peel methanolic extract. BMC Complementary and Alternative Medicine 2012 12:200.

\section{Submit your next manuscript to BioMed Central and take full advantage of:}

- Convenient online submission

- Thorough peer review

- No space constraints or color figure charges

- Immediate publication on acceptance

- Inclusion in PubMed, CAS, Scopus and Google Scholar

- Research which is freely available for redistribution 